\title{
Variants in the ATM gene and breast cancer susceptibility Roger L Milne
}

Address: Genetic \& Molecular Epidemiology Group, Spanish National Cancer Research Center (CNIO), Melchor Fernández Almagro 3 , 28029 Madrid, Spain. Email: rmilne@cnio.es

Published: 22 January 2009

Genome Medicine 2009, I:12 (doi:10.1 186/gm 12)

The electronic version of this article is the complete one and can be

found online at http://genomemedicine.com/content///I//2

(c) 2009 BioMed Central Ltd

\begin{abstract}
It has been established that heterozygous carriers of ataxia-telangiectasia-causing mutations in the ATM gene are at approximately two-fold higher risk of breast cancer. Several studies have attempted to assess the potential implication of the gene's more common variants in breast cancer susceptibility. Three large case-control studies have consistently found no evidence of association for variants with minor allele frequency greater than $5 \%$. Other studies have evaluated associations for coding variants with intermediate frequency (I-5\%), but the results are inconsistent. Larger and/or combined association studies are needed to clarify this issue.
\end{abstract}

Ataxia-telangiectasia mutated $(A T M)$ is the gene that underlies the rare condition after which it was named. Ataxiatelangiectasia (A-T) is a neurodegenerative, autosomal recessive disorder characterized by cerebellar ataxia, telangiectases (damaged small blood vessels) in the conjunctiva and skin, immunological deficiency, hypersensitivity to ionizing radiation and increased risk of cancer [1]. The incidence of A-T has been estimated to be between 1 in 40,000 and 1 in 300,000 [2,3]. One of ATM's most important functions is its central role in the repair of DNA doublestrand breaks. Most A-T patients are compound heterozygous carriers of rare mutations in ATM (mutations with a minor allele frequency [MAF] below $1 \%$ ), and the vast majority of these mutations lead to truncation of the protein, although rare missense mutations that cause A-T have also been identified.

A possible link between A-T and breast cancer was first identified over 20 years ago when it was observed that the relatives of A-T patients had an increased risk of breast cancer [4]. This association has been confirmed in several studies since then [5-9], highlighting $A T M$ as a candidate breast cancer susceptibility gene. Although it seems that common (MAF over $5 \%$ ) variants are not associated with breast cancer risk [10-12], most A-T-causing mutations have been consistently found to be associated with increased risk, with heterozygous carriers at approximately twice the risk of non-carriers $[3,7]$. What remains unclear is the role of other
ATM variants in breast cancer etiology. A recent study [13] found an association between non-A-T-causing missense variants and breast cancer risk, with evidence of a log-linear increase in risk with the number of such variants carried. However, a more recent study by Concannon et al. [14] reported that carrying at least one coding variant (missense or silent) in $A T M$ was associated with protection from cancer of the second breast among patients with breast cancer initially in only one breast (contralateral disease).

\section{A-T-causing variants and breast cancer risk}

Studies of the relatives of A-T patients have consistently suggested that they are at increased risk of breast cancer [6]. Thompson et al. [7] estimated the risk in heterozygous carriers of A-T-causing mutations from A-T case families to be 2.23 times higher ( $95 \%$ confidence interval $[\mathrm{CI}]=1.16-4.28$ ) than that of the general population. Various studies have attempted to assess this association more directly by comparing the frequency of specific ATM mutations in familial breast cancer cases and controls, but few have reported conclusive results because of a lack of statistical power [15-19]. However, a more comprehensive case-control study of coding and splice-site variants across the entire gene by Renwick et al. [3] seems to have resolved this issue. After screening all 62 coding exons and splice junctions in $A T M$ in 443 index cases from families with at least three breast cancers and 521 controls, they directly estimated the 
relative risk associated with A-T-causing mutations to be 2.37 (95\%CI $=1.51-3.78, p=0.0003$ ) [3]. Subsequent large studies of additional specific mutations have given consistent results $[20,21]$, further confirming that the ATM mutations that cause A-T are breast cancer susceptibility alleles. These findings raise the question of whether other ATM variants also influence breast cancer risk.

\section{A role for other ATM coding variants?}

Several case-control studies have evaluated non-A-T-causing coding variants in $A T M$ and their association with breast cancer risk, the majority focusing on missense variants. Such studies include that of Bretsky et al. [22], who identified 20 germline missense variants in ATM by sequencing cDNA from 274 individuals and then tested these in 428 breast cancer cases and 426 controls from the Multiethnic Cohort Study. They found that only two of these variants had MAFs over $5 \%$ and that their allele frequencies were very similar in cases and controls. Most (17/18) of the remaining missense variants had MAFs below $1 \%$. No evidence of association with breast cancer risk was found overall, nor was any found in analyses stratified by ethnic group. However, the statistical power for such lowfrequency variants was limited, particularly in stratified analyses, and thus few firm conclusions could be drawn. In fact, power is a major issue for most studies of these variants because of their relatively low frequency.

Johnson et al. [13] evaluated nine missense variants in ATM in a case-control study comprising 473 women with two primary breast cancers and 2,463 controls. Cases were selected to increase power to the equivalent of that of a study of 3,500 unselected cases and 3,500 controls [13]. This was part of a broader study that included a total of 25 missense variants in BRCA1, BRCA2, ATM, TP53 and CHEK2. Although, individually, only one of the nine $A T M$ variants considered had an associated unadjusted $p$-value less than 0.05, there was stronger evidence that the risk of two primary breast cancers increases with the total number of variant alleles carried across all 25 SNPs in the five genes. The estimated odds ratio (OR) per allele was 1.08 (95\%CI = 1.02-1.14, $p=0.005)$. This increased to $1.30(95 \% \mathrm{CI}=1.15-1.47$, $p=0.00004$ ) when variants with MAF over $10 \%$ were excluded. For the nine ATM missense variants (all with MAF below 10\%), the corresponding OR was 1.27 (95\%CI = 1.04-1.56, $p=0.02)$, corresponding to an estimate OR of 1.13 for a first primary breast cancer.

Concannon et al. [14] recently carried out a populationbased study, nested within a cohort study of first primary invasive breast cancer cases (the WECARE study). They compared the frequencies of variants in ATM in 708 patients subsequently diagnosed with contralateral breast cancer versus 1,397 patients that were never diagnosed with a second primary breast cancer. A total of 240 variants were identified by sequencing the coding exons and flanking intronic regions of the gene in all study participants and then divided into the categories 'rare' and 'common' using a cutoff MAF of $0.5 \%$. Overall, there was weak evidence that carrying any variant was marginally associated with protection from contralateral breast cancer $(\mathrm{OR}=0.8,95 \% \mathrm{CI}=0.7-1.0)$, and slightly stronger evidence that this stemmed from the 15 common variants $(\mathrm{OR}=0.8,95 \% \mathrm{CI}=0.6-0.9$, versus $\mathrm{OR}=$ 1.0, $95 \% \mathrm{CI}=0.8-1.4$ for rare variants). Of these 15 common variants, seven were missense changes and eight synonymous changes, and only one, rs1801516 (encoding an Asp1853Gln change), had a MAF greater than 5\%. Analysis of individual variants revealed that all were associated with ORs of 1.0 or less and four (two missense and two synonymous) had unadjusted $p$-values less than 0.05. The two missense variants were rs1800057 (Pro1054Arg) and rs1801673 (Asp1853Val).

The finding of Concannon et al. [14] for the individual missense variant Pro1054Arg is consistent with nonsignificant results reported in smaller studies [11,22,23], suggesting a possible protective effect against both first primary breast cancer and a second contralateral cancer. However, Johnson et al. [13] estimated an OR of 1.30 (95\%CI $=1.05-1.58)$ for a first primary breast cancer associated with this variant. Furthermore, several other casecontrol studies have reported ORs greater than 1.0 for individual missense variants with frequency greater than 0.5\%. Johnson et al. [13] reported an OR of 1.19 (95\%CI = $0.72-1.83$ ) for Asp1853Val, and ORs of 1.23 (95\% CI = 0.89-1.66) and $1.11(95 \% \mathrm{CI}=0.84-1.43)$ for two other missense variants with MAFs over $0.5 \%$; such associations were not observed in the WECARE study. Similarly, the study by Bretsky et al. [22] reports an individual increased risk-association for a third additional such variant $(\mathrm{OR}=$ 2.36, 95\%CI $=0.84-7 \cdot 58)$. Renwick et al. [3] found no overall association between 35 detected non-A-T-associated missense variants and familial breast cancer, but variantspecific analysis gave ORs ranging from 0.49 (95\%CI = $0.20-1.14)$ to $1.50(95 \% \mathrm{CI}=0.79-2.89)$ for those with a MAF over $0.5 \%$. Results from other studies of specific missense variants have also been mixed [24,25].

It remains unclear how to interpret these findings for coding variants. The overall results of Concannon et al. [14] and Johnson et al. [13] are essentially contradictory, although neither found statistically conclusive evidence either way. It therefore seems that larger sample sizes are required to clarify the role of non-A-T-causing coding variants in ATM in breast cancer susceptibility, in terms of both variantspecific effects and whether they act in a consistent direction and/or act in a log-additive manner.

\section{A role for common polymorphisms?}

Common variations in $A T M$ have been assessed by various studies in relation to breast cancer risk by comparing the 
frequency of single nucleotide polymorphisms (SNPs) with MAF over $5 \%$ in cases and controls. Two large studies (over 1,000 cases) have evaluated selected SNPs and found no evidence of association [26,27]. A Korean study [28] of five SNPs in ATM, comprising 996 cases and 1,181 controls, found some evidence both of individual dominant effects for three SNPs $(0.005<p$-value $<0.05)$ and of differences in the distribution of haplotypes formed by all five SNPs. However, this finding has not been replicated. In fact, three larger case-control studies of tag-SNPs selected to cover common variation across the entire gene have consistently found no evidence of association [10-12]. Tamimi et al. [12] studied five haplotype-tagging SNPs in 1,309 cases and 1,761 controls from the Nurses' Health Study, whereas Einarsdóttir et al. [11] studied seven haplotype-tagging SNPs in 1,579 cases and 1,516 controls from Sweden. In the largest related study to date, Baynes et al. [10] evaluated nine tagSNPs in ATM in 2,278 cases and 2,180 controls from the UK. Although it is possible that gene-environment interaction or other factors might explain different main effects across countries, the balance of evidence suggests that common variants in $A T M$ are not associated with increased breast cancer risk.

\section{Conclusions}

In summary, rare A-T-causing mutations in the ATM gene are associated with a two-fold increased risk of breast cancer relative to the general population. Common polymorphisms do not seem to be associated with susceptibility to the disease, at least in populations of European origin. The role of rare non-A-T-causing coding variants is less clear and statistical power is a limiting factor for most studies. The results from studies so far are inconclusive and inconsistent. Further, large and/or combined association studies are needed to adequately address this issue.

\section{Abbreviations}

A-T, ataxia-telangiectasia; ATM, ataxia-telangiectasia mutated; CI, confidence interval; MAF, minor allele frequency; OR, odds ratio; SNP, single nucleotide polymorphism.

\section{Competing interests}

The author declares that he has no competing interests.

\section{References}

I. Furtado S, Das S, Suchowersky O: A review of the inherited ataxias: recent advances in genetic, clinical and neuropathologic aspects. Parkinsonism Relat Disord 1998, 4:16I-169.

2. Swift M, Morrell D, Cromartie E, Chamberlin AR, Skolnick MH, Bishop DT: The incidence and gene frequency of ataxia-telangiectasia in the United States. Am J Hum Genet 1986, 39:573583.

3. Renwick A, Thompson D, Seal S, Kelly P, Chagtai T, Ahmed M, North B, Jayatilake H, Barfoot R, Spanova K, McGuffog L, Evans DG, Eccles D, Easton DF, Stratton MR, Rahman N: ATM mutations that cause ataxia-telangiectasia are breast cancer susceptibility alleles. Nat Genet 2006, 38:873-875.

4. Swift M, Reitnauer PJ, Morrell D, Chase CL: Breast and other cancers in families with ataxia-telangiectasia. N Engl J Med 1987, 316:1289-1294.

5. Geoffroy-Perez B, Janin N, Ossian K, Lauge A, Croquette MF, Griscelli C, Debre M, Bressac-de-Paillerets B, Aurias A, StoppaLyonnet $\mathrm{D}$, Andrieu $\mathrm{N}$ : Cancer risk in heterozygotes for ataxiatelangiectasia. Int J Cancer 200I, 93:288-293.

6. Swift M, Su Y: Link between breast cancer and ATM gene is strong. BMJ I 999, 318:400.

7. Thompson D, Duedal S, Kirner J, McGuffog L, Last J, Reiman A, Byrd $\mathrm{P}$, Taylor M, Easton DF: Cancer risks and mortality in heterozygous ATM mutation carriers. J Natl Cancer Inst 2005, 97:81 3-822.

8. Easton DF: Cancer risks in A-T heterozygotes. Int J Radiat Biol 1994, 66(6 Suppl):SI77-182.

9. Olsen JH, Hahnemann JM, Borresen-Dale AL, Tretli S, Kleinerman R, Sankila R, Hammarstrom L, Robsahm TE, Kaariainen H, Bregard A, Brondum-Nielsen K, Yuen J, Tucker M: Breast and other cancers in 1445 blood relatives of 75 Nordic patients with ataxia telangiectasia. $\mathrm{Br} J$ Cancer 2005, 93:260-265.

10. Baynes C, Healey CS, Pooley KA, Scollen S, Luben RN, Thompson DJ, Pharoah PD, Easton DF, Ponder BA, Dunning AM: Common variants in the ATM, BRCAI, BRCA2, CHEK2 and TP53 cancer susceptibility genes are unlikely to increase breast cancer risk. Breast Cancer Res 2007, 9:R27.

II. Einarsdóttir K, Rosenberg LU, Humphreys K, Bonnard C, Palmgren J, Li Y, Li Y, Chia KS, Liu ET, Hall P, Liu J, Wedren S: Comprehensive analysis of the ATM, CHEK2 and ERBB2 genes in relation to breast tumour characteristics and survival: a population-based case-control and follow-up study. Breast Cancer Res 2006, 8:R67.

12. Tamimi RM, Hankinson SE, Spiegelman D, Kraft P, Colditz GA, Hunter DJ: Common ataxia telangiectasia mutated haplotypes and risk of breast cancer: a nested case-control study. Breast Cancer Res 2004, 6:R4I 6-R422.

13. Johnson N, Fletcher O, Palles C, Rudd M, Webb E, Sellick G, dos Santos Silva I, McCormack V, Gibson L, Fraser A, Leonard A, Gilham C, Tavtigian SV, Ashworth A, Houlston R, Peto J: Counting potentially functional variants in BRCAI, BRCA2 and ATM predicts breast cancer susceptibility. Hum Mol Genet 2007, I6: I05 I- 057.

14. Concannon P, Haile RW, Borresen-Dale AL, Rosenstein BS, Gatti RA, Teraoka SN, Diep TA, Jansen L, Atencio DP, Langholz B, Capanu M, Liang X, Begg CB, Thomas DC, Bernstein L, Olsen JH, Malone KE, Lynch CF, Anton-Culver H, Bernstein JL: Variants in the ATM gene associated with a reduced risk of contralateral breast cancer. Cancer Res 2008, 68:6486-649l.

15. Bernstein JL, Bernstein L, Thompson WD, Lynch CF, Malone KE, Teitelbaum SL, Olsen JH, Anton-Culver H, Boice JD, Rosenstein BS, Borresen-Dale AL, Gatti RA, Concannon P, Haile RW: ATM variants $727 I T>G$ and IVSI0-6T $>$ G among women with unilateral and bilateral breast cancer. Br J Cancer 2003, 89:15I3-1516.

16. Bernstein JL, Teraoka S, Southey MC, Jenkins MA, Andrulis IL, Knight JA, John EM, Lapinski R, Wolitzer AL, Whittemore AS, West D Seminara D, Olson ER, Spurdle AB, Chenevix-Trench G, Giles GG Hopper JL, Concannon P: Population-based estimates of breast cancer risks associated with ATM gene variants c.727IT>G and c. I066-6T > G (IVSI0-6T $>$ G) from the Breast Cancer Family Registry. Hum Mutat 2006, 27: I I 22-I I 28

17. Chenevix-Trench G, Spurdle AB, Gatei M, Kelly H, Marsh A, Chen X, Donn K, Cummings M, Nyholt D, Jenkins MA, Scott C, Pupo GM, Dork T, Bendix R, Kirk J, Tucker K, McCredie MR, Hopper JL, Sambrook J, Mann GJ, Khanna KK: Dominant negative ATM mutations in breast cancer families. J Natl Cancer Inst 2002, 94:205-2 I5.

18. Szabo $\mathrm{Cl}$, Schutte M, Broeks A, Houwing-Duistermaat J], Thorstenson YR, Durocher F, Oldenburg RA, Wasielewski M, Odefrey F, Thompson D, Floore AN, Kraan J, Klijn JG, van den Ouweland AM, Wagner TM, Devilee P, Simard J, van 't Veer LJ, Goldgar DE, MeijersHeijboer $\mathrm{H}$ : Are ATM mutations $727 \mathrm{IT} \rightarrow \mathrm{G}$ and IVSI0-6T $\rightarrow$ G really high-risk breast cancer-susceptibility alleles? Cancer Res 2004, 64:840-843.

19. Lindeman G], Hiew M, Visvader JE, Leary J, Field M, Gaff CL, Gardner RJ, Trainor K, Cheetham G, Suthers G, Kirk J: Frequency of the ATM IVSI $0-6 \mathrm{~T} \rightarrow \mathrm{G}$ variant in Australian multiple-case breast cancer families. Breast Cancer Res 2004, 6:R40I-R407.

20. Bogdanova N, Cybulski C, Bermisheva M, Datsyuk I, Yamini P, Hillemanns P, Antonenkova NN, Khusnutdinova E, Lubinski J, Dork T: A 
nonsense mutation (EI978X) in the ATM gene is associated with breast cancer. Breast Cancer Res Treat 2008 [in press].

21. Pylkas K, Tommiska J, Syrjakoski K, Kere J, Gatei M, Waddell N, Allinen $M$, Karppinen SM, Rapakko K, Kaariainen $\mathrm{H}$, Aittomaki $\mathrm{K}$, Blomqvist C, Mustonen A, Holli K, Khanna KK, Kallioniemi OP, Nevanlinna H, Winqvist R: Evaluation of the role of Finnish ataxiatelangiectasia mutations in hereditary predisposition to breast cancer. Carcinogenesis 2007, 28: 1040- 1045.

22. Bretsky P, Haiman CA, Gilad S, Yahalom J, Grossman A, Paglin S, Van Den Berg D, Kolonel LN, Skaliter R, Henderson BE: The relationship between twenty missense ATM variants and breast cancer risk: the Multiethnic Cohort. Cancer Epidemiol Biomarkers Prev 2003 12:733-738.

23. Broeks A, Braaf LM, Huseinovic A, Schmidt MK, Russell NS, van Leeuwen FE, Hogervorst FB, Van 't Veer LJ: The spectrum of ATM missense variants and their contribution to contralateral breast cancer. Breast Cancer Res Treat 2008, 107:243-248.

24. Schrauder M, Frank S, Strissel PL, Lux MP, Bani MR, Rauh C, Sieber CC, Heusinger K, Hartmann A, Schulz-Wendtland R, Strick R, Beckmann MW, Fasching PA: Single nucleotide polymorphism DI853N of the ATM gene may alter the risk for breast cancer. J Cancer Res Clin Oncol 2008, 134:873-882.

25. Stredrick DL, Garcia-Closas M, Pineda MA, Bhatti P, Alexander BH, Doody MM, Lissowska J, Peplonska B, Brinton LA, Chanock SJ, Struewing JP, Sigurdson AJ: The ATM missense mutation p.Ser49Cys (c. I46C>G) and the risk of breast cancer. Hum Mutat 2006, 27:538544.

26. Tommiska J, Jansen L, Kilpivaara $\mathrm{O}$, Edvardsen $\mathrm{H}$, Kristensen $\mathrm{V}$, Tamminen A, Aittomaki K, Blomqvist C, Borresen-Dale AL, Nevanlinna $\mathrm{H}$ : ATM variants and cancer risk in breast cancer patients from Southern Finland. BMC Cancer 2006, 6:209.

27. Ye C, Dai Q, Lu W, Cai Q, Zheng Y, Shu XO, Gu K, Gao YT, Zheng $\mathrm{W}$ : Two-stage case-control study of common ATM gene variants in relation to breast cancer risk. Breast Cancer Res Treat 2007, 106:121-126.

28. Lee KM, Choi JY, Park SK, Chung HW, Ahn B, Yoo KY, Han W, Noh DY, Ahn SH, Kim H, Wei Q, Kang D: Genetic polymorphisms of ataxia telangiectasia mutated and breast cancer risk. Cancer Epidemiol Biomarkers Prev 2005, 14:82 I-825. 